\title{
STRATEGY AND STRUGGLE OF STREET VENDORS IN PASAR PAGI DISTRIC OF SAMARINDA
}

\section{STRATEGI DAN PERJUANGAN PEDAGANG KAKI LIMA (PKL) DI KELURAHAN PASAR PAGI KOTA SAMARINDA}

\author{
Rossy Capriati ${ }^{1}$, Purwaningsih ${ }^{2}$ \\ Universitas Mulawarman, Indonesia
}

Email Correspondence: psd@ fisip.unmul.ac.id

\begin{abstract}
:
Strategies and Struggles of Street Vendors in Pasar Pagi Village, Samarinda City. This thesis stems from my curiosity about the reasons these actors choose street vendors as their realm of work. As well as regarding field practices and competition between fellow business actors from relatively small to relatively large capital. Practices in the field of actors in the realm of business do not only rely on material capital but also on social capital, cultural capital, and symbolic capital as a form of strategy for the actors to maintain their business. Street vendors, as businessmen with relatively small capital, are not only competing with fellow street vendors, but also with large capital owners. The strategy used by street vendors is to collect capital and convert their capital even though their capital is relatively small. There are various forms of capital and habitus that are owned by street vendors. This is all as a support for the actors to be able to continue to survive in this realm. The street vendor is a practice from the flow of life that is not on their side. The minimal material capital and the exclusion of these actors with large investors make them more struggling and have a strategy to be able to maintain their business.
\end{abstract}

Keywords: Strategy and Struggle, Street Vendors, Pasar Pagi Samarinda

\begin{abstract}
ABSTRAK:
Strategi dan Perjuangan Pedagang Kaki Lima di Kelurahan Pasar Pagi Kota Samarinda. Skripsi ini bermula dari rasa ingin tahu saya tentang alasan para aktor ini memilih pedagang kaki lima sebagai ranah pekerjaan yang mereka jalani. Serta tentang praktik lapangan dan persaingan antara sesama pelaku bisnis dari yang bermodalkan relatif kecil sampai yang bermodalkan relatif besar. Praktik di lapangan para pelaku di ranah bisnis nyatanya bukan hanya mengandalkan modal material saja melainkan juga modal social, modal budaya dan modal simbolik sebagai bentuk strategi para actor dalam mempertahankan usahanya. Pedagang kaki lima sebagai pelaku bisnis yang bermodalkan relative kecil nyatanya bukan hanya bersaing dengan sesame pedagang kaki lima akan tetapi juga dengan para pemilik modal-modal besar. Strategi yang digunakan para pedagang kaki lima dari mengumpulkan modal dan mengkonversikan modal mereka lakoni walupun modal mereka relatf kecil. Bentuk variasai-variasi modal dan habitus yang dimiliki oleh pedagang kaki lima beraneka ragam. Ini semua sebagai penunjang para aktor untuk dapat terus bertahan dalam ranah ini. Pedagang kaki lima merupakan praktik dari arus kehidupan yang tidak memihak kepada mereka. Modal material yang minim serta tersisihkannya para aktor ini dengan para pemodal besar membuat mereka lebih berjuang dan memiliki strategi untuk dapat mempertahankan usaha mereka.
\end{abstract}

\section{Kata Kunci: Strategi Dan Perjuangan, Pedagang Kaki Lima, Pasar Pagi Samarinda}

\section{Article Info}

Received

January 2020

Accepted

January 2020

Published

DOI

: January 2020

: https://doi.org/10.30872/psd.v1i1.13

\section{Copyright and License}

Authors retain copyright and grant the journal right of first publication with the work simultaneously licensed under a Creative Commons Attribution 4.0 International License that allows others to share the work with an acknowledgment of the work's authorship and initial publication in this journal. 


\section{PENDAHULUAN}

Pedagang kaki lima yang dipinggirkan, ternyata kian hari kian bertambah banyak. Kegiatan pedagang kaki lima di perkotaan berkembang sangat pesat. Permasalahan yang timbul akibat aktivitas pedagang kaki lima tersebut antara lain kebersihan, keindahan, ketertiban, pencemaran dan kemacetan lalu lintas di perkotaan. Keadaan ini dianggap mengganggu, tetapi di sisi lain pedagang kaki lima ini memberikan kontribusi yang besar dalam aktivitas ekonomi dan kesejahteraan masyarakat terutama golongan ekonomi lemah. pedagang kaki lima ini merupakan ciri ekonomi kerakyatan yang bersifat mandiri dan menyangkut hajat hidup orang banyak.

Pedagang kaki lima sebagai bagian dari sektor informal kota. pedagang kaki lima merupakan lahan pekerjaan yang terbuka bagi siapa saja. Bidang ini juga tidak memerlukan keahlian khusus dari pelakunya, dan ini merupakan penyebab bertambahnya pedagang kaki lima di Kota Samarinda. Munculnya pedagang kaki lima bukan hanya berbekal gerobak atau meja sebagai tempat barang dagangan mereka akan tetapi mereka mempunnyai kemandirian, kelenturan dan keefisienan usaha. Karakteristik pedagang kaki lim dalam berjualan adalah selalu mencari daerah-daerah strategis. Daerah strategis yang dimaksudkan adalah daerah yang banyak dilalui penduduk kota meskipun seringkali daerah-daerah tersebut dilarang untuk berdagang, seperti trotoar, pinggir jalan maupun kawasan sekitar pasar merupakan tempat-tempat yang paling banyak dijelajahi oleh para pedagang kaki lima. Tidak dapat dihindari, bahwa ada sebagian masyarakat yang tertinggal atau ditinggalkan dalam proses perkembangan yang menyebabkan timbulnya permasalahan seperti gelandangan, pengemis, pengamen, pengangguran. Berbagai permasalahan sosial ini muncul akibat ketidakpuasan yang semakin meningkat semenjak krisis ekonomi, krisis ekonomi berdampak pada meningkatnya angka pengangguran dan membengkaknya jumlah penduduk miskin. Krisis ekonomi mengakibatkan makin banyak penduduk yang tidak mampu menjangkau pendidikan. Selain itu lemahnya tingkat pendidikan juga berakibat pada lemahnya pengembangan dan penerapan ilmu pengetahuan teknologi sehingga belum dimanfaatkan secara optimal dalam kegiatan ekonomi, sosial dan budaya yang pada gilirannya menjadi hambatan dalam menghadapi kerjasama dan persaingan global. Pedagang kaki lima, yaitu mereka yang bekerja dengan memanfaatkan situasi, tempat dan keramaian yaitu dengan berjualan di trotoar atau di tempat umum lainnya. Pedagang kaki lima termasuk sektor Usaha Mikro Kecil Menengah (UMKM). Pedagang kaki lima seringkali didefinisikan sebagai suatu usaha yang memerlukan modal relatif sedikit, berusaha dalam bidang produksi dan penjualan untuk memenuhi kebutuhan kelompok konsumen tertentu. Usahanya dilaksanakan pada tempat-tempat yang dianggap strategis dalam lingkungan yang informal. Sektor usaha pedagang kaki lima tersebut seringkali menjadi sasaran bagi masyarakat dan pendatang baru untuk membuka usaha di daerah perkotaan. Hal ini disebabkan karena adanya ciri khas dan relatif mudahnya membuka usaha (tidak memerlukan modal yang besar) di sektor tersebut.

Dalam penelitian ini penulis akan menggunakan landasan teori dari salah satu tokoh sosiolog dari Perancis yaitu Pierre Bourdieu tentang praktik. Praktik merupkan konsep-konsep tentang otonomi relatif, trajektori personal dan kelas, dan terutama sifat dasar strategi dan perjuangan posisi di dalam sebuah ranah. Dalam teorinya Bourdiue berusaha menghubungkan gagasan-gagasan teoritisnya dengan riset empiris yang berdasarkan pada kehidupan sehari-hari. Teori yang di tawarkan oleh Bourdieu adalah teori praktik. Praktik dalam pemahaman Bourdieu dirumuskan : ( Habitus x Modal ) + Ranah = Praktik. Rumus ini mengganti setiap relasi sederhana antar individu dan struktur dengan relasi antara habitus dan ranah yang melibatkan modal.

\subsection{Pandangan Bourdieu Tentang Dunia Kehidupan}

Kehidupan sosial terjadi dalam sebuah ranah sosial yang merupakan suatu arena perjuangan yang mencoba untuk membedakan dirinya dengan yang lain dan mendapatkan modal yang berguna dan berharga di arena tersebut. Hal yang terpenting adalah mendapatkan rejeki yang halal yang dapat digunakan untuk memenuhi kehidupan. Praktik-praktik yang digunakan para aktor dalam berusaha menjajakan dagangannya pada umumnya merasa sedikit malu. Oleh karena tuntutan kehidupan dan telah merasakan nikmatnya memperoleh keuntungan, maka pelan-pelan rasa malu itu hilang. Para aktor itu bahkan bertekat untuk terus mengembangkan usahanya. Dalam kehidupan sosial praktik-praktik yang dilakukan setiap aktor memang sangat beragam. Bagi mereka yang hanya memiliki sedikit keterampilan dalam sebuah ranah perjuangan yang dinamis menjadi suatu tolak ukur untuk mereka berkembang dan mengembangkan keterampilan mereka yang sangat minim di sektor informal. Kehidupan sosial untuk para aktor di sektor informal memberikan suatu kesempatan yang sangat berarti bagi mereka untuk dapat mendiri dan tidak bergantung pada orang lain dan mandiri utuk lepas dari orang tua dengan cara mengadu nasib. Suatu ranah menjadi tempat perjuangan dan persaingan dimana para aktor bisa memberikan pengaruh ataupun dipengaruhi. Aktor yang memiliki modal lebih besar cenderung akan menjadi aktor yang menguasai dalam tempat- tempat perjuangan. Aktor pemilik modal memiliki aturan sendiri untuk mencapai tujuannya. Aktor pemilik modal menjadi aktor yang mendominasi bagi para marginalisasi. Kekuasaan pemilik modal dapat menentukan jalan keuntungan-

Progress in Social Development: Volume 1 No 1 Januari 2020 
keuntungan tertentu pada ranah perjuangan. Pertaruhannya terletak pada modal yang diinfestasikan dan dapat memungkinkan menjadi sebuah aktor yang mendominasi. Modal yang dimiliki merupakan suatu sarana untuk mendapatkan tujuan.

\subsection{Konsep-Konsep Dasar Pemikiran Bourdieu}

Agen tidak hidup di ruang kosong, agen selalu terlibat dalam ranah sosial. Jika habitus adalah sejarah yang menubuh dalam agen, maka dunia sosial adalah sejarah yang diobjektifikasi dalam benda dan institusi, "dalam bentuk struktur dan mekanisme". Praktik dihasilkan dari pertemuan antara dua sejarah ini, sejarah dalam tubuh dan sejarah dalam dunia. "Tubuh berada dalam dunia sosial, tapi dunia sosial juga berada dalam tubuh" dalam bentuk habitus.

Batas sebuah ranah dan hubungannya dengan ranah-ranah lain tidak pernah tetap. Ranah selalu berubah dan justru menjadi bagian dari pertaruhan yang diperjuangkan. Ranah lebih bersifat dinamis karena di dalamnya selalu terjadi perubahan, baik karena pertarungan internal antara berbagai posisi di dalamnya maupun karena pergesekannya dengan ranah-ranah lain. Ranah-ranah ini berada dalam ranah kekuasaan. Sebuah meta-ranah di mana ranah-ranah yang berbeda dan para agen yang terlibat di dalamnya saling bersaing untuk menentukan prinsip penyusunan hierarki antar-ranah dan prinsip konversi atau nilai tukar antar-jenis modal yang dihargai dalam masing-masing ranah.

\subsection{Praktik}

Praktik merupakan salah satu konsep utama bourdieu. Dalam teori praktik untuk melepaskan diri dari oposisi klasik subjektivisme dan objektivisme, di samping habitus, arena, dan kapital. Teori praktik yang ditawarkan bourdieu menggugat subjektivisme yang meletakkan subjek intelektual pada peran utama pembentukan dunia tanpa memperhitungkan konteks ruang dan waktu yang melatar belakanginya. Praktik merupakan dinamika dialektis antara internalisai segala sesuatu yang dialami dan diamati dari luar diri pelaku dengan pengungkapan diri dari segala sesuatu yang telah terinternalisasi dan menjadi bagian dari diri pelaku.

\subsection{Modal}

Modal merupakan konsep dalam ilmu ekonomi tetapi dipakai oleh Bourdieu. Modal mampu dihubungkan dengan hubungan-hubungan kekuasaan. Bourdien menambahkan modal social, modal budaya dan modal ekonomi. Modal social merupakan suatu jaringan- jaringan atau hubungan-hubungan yang merupakan sumber daya yang berguna dalam penentuan reproduksi kedudukan-kedudukan social. Modal budaya ialah merupakan cara pembawaan, sopan santun dan cara bergaul yang juga berperan terhadap kedudukan social. Dan modal simbolik yang tidak lepas dari kekuasaan simbolik yang memungkinkan mendapatkan setara dengan apa yang diperoleh melalui kekuasaan fisik dan ekonomi. Tetapi bagi kaum informal (pedagang kaki lima) modal simbolik ini merupakan kekhasan bagi para actor agar mudah diingat oleh para konsumennya.

\subsection{Habitus}

Habitus diadopsi melalui pengasuhan dan pendidikan. konsep tersebut digunakan pada tingkatan individu, 'a system of acquired dispositiions functioning on the practical level as categories of perception and assessment...as well as beig the organizing priciples of action'. Bourdieu berpendapat bahwa perjuangan demi distingsi sosial merupakan dimensi fundamental dari seluruh kehidupan sosial menurut Bourdieu dalam Bagus Talkwin (2005: xi). Istilah ini merujuk kepada ruang sosial dan terjalin dengan sistem disposisi (habitus). Dalam pengantarnya Bagus Takwim menjelaskan, bahwa bordieu mengartikan habitus sebagai "suatu sistem disposisi yang berlangsung lama dan berubah-ubah (durable, trnasponsible disposition) yang berfungsi sebagai basis generatif bagi praktik-praktik yang terrstruktur dan terpadu secara objektif". sedangkan ranah oleh Bourdieu diartikan sebagai jaringan relasi antar posisi-posisi objektif dalam suatu tatanan sosial yang hadir terpisah dari kesadaran dan kehendak individual

\subsection{Ranah Pekerjaan Pedagang Kaki Lima Kelurahan Pasar Pagi Kota Samarinda}

Ranah merupakan tempat persaingan dan perjuangan. Pelaku dalam suatu bidang harus menguasai kode-kode dan aturan main. Dalam setiap bidang, pelaku harus bersaing untuk mendominasi dan oleh karena itu dalam setiap bidang ada aturan main tersendiri. Keberhasilan dan strategi para pelaku tergantung pada struktur modal yang dimiliki dalam lingkup sosial tersebut. Dalam pola-pola untuk memperoleh posisi-posisi kehormatan, tindakan para pelaku menggunakan strategi-strategi yang tepat dan tersedia untuk mempererat posisi mereka di dalam ranah menjadi semakin jelas. Dunia kerja di KotaSamarinda hanya ramah bagi mereka yang memiliki modal-modal material dan simbolik yang dapat diterima sebagai pekerja pada sektor pemerintahan maupun swasta. Semakin tahun dunia kerja menuntut agar klasifikasi calon pekerja harus memiliki kemampuan yang benar-benar terampil. Modal simbolik yang diperoleh akan membawa pada dunia 
kerja yang diinginkan akan terasa lebih mudah. Dilain pihak mereka yang tidak memiliki modal simbolik tersebut justru akan mendapatkan kesulitan untuk masuk dalam dunia kerja, bahkan tidak mendapat tempat pada sektor pemerintahan. Ranah pedagang kaki lima ada pada sektor informal. Para aktor pekerja yang tidak tertampung di sektor formal akan berpartisipasi di sektor informal. Salah satu sektor informal yang banyak diminati bagi para pelaku yang minim modal adalah menjadi pedagang kaki lima. Pedagang kaki lima di kota Samarinda kian lama kian bertambah banyak. Pedagang kaki lima banyak tersebar di sudut-sudut kota. Dapat di lihat di Kelurahan Pasar Pagi banyaknya pedagang kaki lima yang kian hari kian bertambah banyak karena lokasi ini yang dianggap strategis. Daerah Kelurahan Pasar Pagi yang dianggap strategis karena selain daerah ini mempunyai pusat perbelanjaan seperti mall dan toko-toko besar daerah ini juga merupakan pusat kota yang sering dijamah oleh masyarakat Kota Samarinda maupun luar daerah

\section{METODE}

Dalam penelitian ini penulis akan menggunakan metode penelitian kualitatif. Penulis akan meminjam metode yang pernah digunakan oleh Clifford Geertz dalam meneliti agama serta kebudayaan masyarakat Jawa yaitu metode etnografi. Dengan metode ini penulis dapat memberikan sebuah penafsiran- penafsiran kejadian di lapangan. Jadi peneliti harus melihat dan bergulat langsung dengan subjek yang di amati. Peneliti membekali diri dengan teori- teori yang berkaitan tetapi bukan untuk membingkai subjek yang di amati namun sebagai bekal untuk pengamatan di lapangan. Peneliti juga melakukan pendekatan interpretatif yang mencari pemahaman makna dari ekspresi kebudayaan dari pada sekedar mencari hubungan sebab-akibat Dalam penulisan ini penulis akan meneliti mengenai strategi dan perjuangan pedagang kaki lima dalam memperjuangkan kehidupannya di ranah sosial. Dengan meminjam metode etnografi yang di gunakan Clifford Geertz penulis bertujuan menggali informasi secara mendalam dengan sumber yang luas. Dengan teknik pengumpulan data 'observatory participan' yang mengharuskan peneliti secara langsung ada dalam sebuah masyarakat atau komunitas sosial tertentu. Penulis juga menggunakan metode penulisan dengan menggunakan metode 'thick description' yang dimaksudkan agar penulis mampu mengidentifikasi usaha apakah yang disebut dengan etnografi. Metode ini juga bertujuan agar penulis dapat mendeskripsiskan apapun tentang perilaku manusia yang bersifat mendalam. Dalam pengertiannya bahwa deskripsi tersebut tergantung pada lapisan ragam makna yang diberikan manusia pada semua tindakan mereka

\section{HASIL DAN PEMBAHASAN}

Kelurahan Pasar Pagi merupakan ranah bisnis yang cukup strategis di Kota Samarinda. Sebagai ranah bisnis, Kelurahan Pasar Pagi di anggap strategis karena merupakan pusat kota yang menjadi area pertemuan seluruh Angkutan Kota yang ada di Samarinda. Angkutan Kota dari segala jurusan yang ditandai dengan perbedaan warnanya, dari yang berwarna hijau, biru dan merah akan ditemui di area ini. Selain itu ada Terminal Pasar Pagi yang juga menjadi tujuan angkutan kota dari daerah Samarinda Sebrang. Di Kelurahan Pasar Pagi terdapat berbagai bisnis dengan beragam skala seperti: mall Mesra Indah, pasar induk, toko-toko besar dan banyaknya pedagang kaki lima. Hal ini menjadikan para konsumen banyak mendatangi wilayah ini untuk berbelanja. Dalam ranah kehidupan di Kelurahan Pasar Pagi bahwasannya ranah ini merupakan arena bagi para pelaku bisnis. Habitus-habitus para agen pelaku bisnis ini terlihat sangat beragam. Keberagaman habitus terjadi baik pada para pemilik modal yang besar dan pemilik modal yang relatif kecil. Hal ini dikarenakan para pemilik modal relatif kecil paling tidak harus lebih berjuang lebih keras. Pemilik modal materi yang relatif kecil terutama para pedagang kaki lima tentunya mencari barang dagangan yang akan mereka dagangkan kembali. Ini semua dikarenakan strategi-strategi perjuangan tidak sama antara pemilik modal besar dan pemilik modal kecil. Hal ini dikarenakan pemilik modal yang besar tentunya memiliki lokasi berdagang yang tetap dan tidak berpindah. Para pemilik modal kecil seperti para pedagang kaki lima lebih bertaruh dalam perjuangan mempertahankan dan mengembangkan usahanya. Jumlah mereka yang relatif banyak dan membuat persaingannya juga meningkat. Persaingan sesama pemilik modal kecil tentunya ada pada tempat lokasi berdagang, produk, pelayanan dan penyusunan barang. Semakin dekat lokasi berdagang dan sering ditemui konsumen maka dagangan akan semakin laris. Begitu juga dari segi pelayanan yang dilakukan oleh para pemilik modal kecil ini, mereka harus ramah dalam melayani konsumen.

\subsection{Karakteristik Pedagang Kaki Lima Di Kelurahan Pasar Pagi}

Para pedagang kaki lima yang ada di ranah Bisnis Pasar Pagi, memiliki koleksi modal yang sangat bervariasi. Variasi modal ini diwarnai olah perbedaan trajektori kehidupan yang berlangsung dari lahir hingga dewasa. Perbedaan koleksi modal juga menunjukkan sebuah keberhasilan ataupun kegagalan mereka dalam memilih strategi-strategi akumulasi modal yang mereka pilih sepanjang perjuangan bisnis mereka. Variasi koleksi modal-modal pedagang kaki lima bisa saya gambarkan dalam table dan uraian berikut ini 


\subsection{Modal- Modal Material Pedagang Kaki Lima}

Berbicara tentang modal material pedagang kaki lima ini tidak terlepas dari perlengkapan apa saja yang digunakan pedagang kaki lima yang bersifat material. Modal yang digunakan pedagang kaki lima relatif kecil dan perlengkapan materialnya juga sangat minim. Dapat diartikan modal material yang digunakan pedagang kaki lima ini sangat jauh dari kesan mewah. Itu juga yang membuat para pedagang kaki lima ini tidak memiliki lokasi berdagang yang jauh dari kata layak. Dengan perlengkapan seadanya ini yang membuat para aktor justru mampu bertahan dengan strategi serta kekuatan-kekuatan para aktor ini.

\subsection{Modal- Modal Sosial Pedagang Kaki Lima}

Pedagang kaki lima menjalin hubungan sosial dengan individu yang mampu mempertahankan usahanya dan sebagai tempat perlindungan bagi para aktor ini. Dengan menjalin hubungan yang baik para aktor ini menganggap akan tercipta hubungan kekerabatan yang baik juga. Modal sosial tidak lepas dengan hubunganhubungan serta jaringan-jaringan dengan individu yang lain. Para pedagang kaki lima ini membina hubungan yang baik bukan hanya dengan konsumen tetapi juga dengan sesama pedagang kaki lima, para pemilik modal yang relatif besar, boss pemodal serta aparatur pemerintahan.

\subsection{Modal- Modal Budaya Pedagang Kaki Lima}

Modal budaya merupakan pembawaan dari dalam diri para aktor. Sopan santun, pembawaan dari individu dan cara berbicara adalah modal budaya yang dibutuhkan oleh para pedagang kaki lima ini. Modal budaya tidak lepas dengan bagaimana cara berinteraksi dengan orang lain. Modal budaya yang dilakukan oleh para pedagang kaki lima ini bukan hanya dengan konsumen tetapi juga dengan sesama pedagang kaki lima, para pemilik modal (boss bandar peminjam modal), serta para pemilik modal besar. Modal budaya yang dilakukan oleh para pedagang kaki lima ini bertujuan untuk menarik minat konsumen. Dengan menyapa dengan ramah dan santun para pedagang kaki lima ini menawarkan barang dagangannya. Bukan hanya dengan konsumen tetapi juga dengan sesama pedagang kaki lima agar tercipta hubungan relasi yang baik sesama pedagang

\subsection{Modal- Modal Budaya Pedagang Kaki Lima}

Modal- Modal Simbolik Pedagang Kaki Lima Pedagang Kaki lima memiliki modal simbolik yang berbeda dari setiap aktornya. Modal simbolik yang dimiliki pedagang kaki lima bukanlah sebuah kekuasaan simbolik. Modal simbiolik yang dimiliki pedagang kaki lima adalah seperti apa yang mereka gunakan dan mereka pakai. Modal simbolik biasanya tidak lepas dari sebuah kekuasaan. Modal simbolik dapat dilihat dari tingkat pendidikan serta barang yg dimiliki, serta apa saja yang mempunnyai nilai simbol. Para pedagang kaki lima juga memiliki nilai simbolik itu. Nilai simbolik itu bukan merupakan kekuasaan dan juga bukan merupakan pendidikan. Karena kebanyakan dari mereka yang berjuang di dalam ranah bisnis ini memiliki pendidikan yang rendah. Modal simbolik mereka merupakan suatu perlengkapan untuk berdagang yang dapat diingat selalu oleh para konsumen. Kekhasan dari para pedagang kaki lima ini dapat dilihat dari perlengkapan yang mereka gunakan. Perlengkapan yang mereka gunakan harus memiliki nilai simbol agar dapat mudah diingat oleh para konsumen.

\subsection{Habitus- habitus Pedagang Kaki Lima Kawasan Pasar Pagi}

Pedagang kaki lima menciptakan habitusnya sendiri. Habitus untuk jam kerja juga diatur oleh para aktor itu sendiri. Perjuangan serta persaingan yang membuat mereka dapat menciptakan habitus pekerjaan mereka sendiri. Habitus pedagang kaki lima dalam berdagang jauh lebih berstrategi. Karena Habitus mereka ada yang mencari barang dagangannya terlebih dahulu untuk didagangkannya kembali.

\subsection{Manajemen Waktu Pedagang Kaki Lima}

Sebagai pelaku bisnis yang bergerak di sektor informal, pedagang kaki lima dapat mengatur waktunya sendiri. Dari setiap informan tentunya memiliki manajemen waktu yang berbeda-beda. Bentuk rill dalam manajemen waktu pedagang kaki lima sangat beraneka ragam. Variasi dari manajemen waktu para aktor ini tergantung pada sasaran konsumen yang ingin mereka jamah. Para aktor ini tentunya memiliki alasan yang beragam dalam memanajemen waktu mereka dalam berdagang dan kehidupan sehari-hari mereka dalam beraktifitas. Manfaat para aktor ini dalam memanajemen waktu agar dapat mebagi waktu dalam berdagang, mempersiapkan dagangan serta tugas mereka di rumah. 


\subsection{Manajemen Keuangan Pedagang Kaki Lima}

Bentuk manajemen keuangan dari setiap informan tentunya sangat berbeda. Ada dari para aktor yang menyimpan uangnya di bank, ada yang disimpan di rumah, ada yang dipinjamkan sesama pedagang dan ada pula yang mengikuti arisan. Dengan alasan masing-masing dari setiap aktor tentunya hasil dari berdagang itu sebagai bentuk investasi mereka. Ada pula aktor yang hanya menyimpan uangnya di rumah untuk memenuhi kebutuhan keluarga sehari-hari. Mengikuti arisan juga di ikuti dari salah satu informan sebagai bentuk perputaran uang agar apabila ada keperluan uang itu dapat digunakan. Tetapi dari aktor ada juga yang tidak sungkan untuk memijamkan uangnya ke sesama pedagang. Dengan alasan untuk membantu sesama pedagang. Bentuk investasi yang dilakukan informan yang menyimpan uangnya di bank yang dilakukan salah satu aktor dengan tujuan untuk menyekolahkan anaknya. Ada pula yang ingin membangun rumah untuk bekal dimasa tua. Walaupun hanya pelaku bisnis yang bermodalkan relatif kecil ternyata dari salah satu informan ini ada pula yang mampu menyekolahkan anaknya sampai ke jenjang perguruan tinggi. Bentuk menyekolahkan anak ini juga merupakan investasi para aktor untuk dapat bisa dapat penghidupan yang lebih layak karena memiliki harapan yang besar kepada anaknya.

\subsection{Manajemen Emosi Pedagang Kaki Lima}

Bentuk manajemen emosi adalah bagaimana bentuk individu dapat mengontrol dirinya saat berhadapan dengan suatu persoalan yang sulit. Manajemen emosi para pedagang kaki lima harus lebih terkontrol saat menghadapi konsumen agar konsumen tetap merasa nyaman saat berbelanja di lapak mereka. Dalam berdagang perlunya manajemen emosi agar dapatmelayani konsumen dengan baik. Sikap yang baik serta dengan keramah tamahan saat melayani akan menjadi nilai plus pada saat berdagang. Bergelut dengan terik matahari, hawa yang panas, debu serta aroma-aroma yang terkadang kurang sedap harus dihadapi oleh pedagang kaki lima ini. Tentunya dengan keadaan seperti ini para aktor harus bisa lebih mengontrol emosi mereka

\subsection{Manajemen Persuasi Pedagang Kaki Lima}

Bentuk Manajemen Persuasi bagi para pedagang kaki lima adalah tentang bagaimana aktor ini mampu meyakinkan konsumen untuk dapat berbelanja di lapak mereka. Bentuk rill di lapangan tentang cara aktor meyakinkan para konsumen dengan cara menyapa konsumen dengan ramah dan mampu mempengaruhi konsumen bahwasaanya barang yang mereka jual baik dan bermutu. Ini merupakan salah satu cara yang jitu bagaimana para aktor ini membentuk sebuah pencitraan barang dagangannya agar dapat dibeli oleh konsumen. Cara-cara jitu lainnya yang dilakukan oleh para aktor untuk menarik minat konsumen dengan cara memajang harga barang dagangan mereka. Tentunya dengan memajang harga yang murah dibandingkan harga di mall tentunya para konsumen akan berdatangan ke lapak pedagang kaki lima tersebut. untuk meyakinkan minat konsumen juga sering para aktor lakukan dengan mengizinkan mencicipi barang dagangan mereka

\subsection{Keterampilan Memasak Pedagang Kaki Lima}

Bentuk rill di lapangan bahwasannya para aktor ini dapat memasak bukan karena khursus memasak untuk menjadi profesional. Akan tetapi para aktor ini memiliki keterampilan memasak ini secara otodidak karena merupakan tuntutan pekerjaan mereka. Ada juga dari salah satu aktor yang terbiasa memasak karena terbiasa semenjak dini di ruang lingkup keluarganya. Sehingga pada saat terjun ke pekerjaan yang membutuhkan keterampilan memasak sebagai besicnya mereka sudah tidak canggung lagi. Agar dapat memasak masakan yang beraneka ragam aktor ini juga dapat belajar pada teman dan sanak saudara. Melihat dari kekurangan rasa dan jenis masakan yang mereka dagangkan membuat mereka selalu ingin mengetahui cara mebuat masakan tersebut. dengan menambah wawasan tentang memasak tentunya masakan mereka bisa akan lebih lezat. Dan jajanan yang dihidangkan juga menjadi beraneka ragam. Karena dengan semakin bervariasinya masakan yang di buat dan bertambahnya cita rasa ini juga merupakan pendukung agar dagangan mereka laris terjual.

\subsection{Kemandirian Pedagang Kaki Lima}

Kemandirian ini juga tercipta akibat terbiasa mereka dari kecil yang bersifat mandiri. Contohnya dari salah satu informan yang mengaku bahwasannya pada umur 10 tahun sudah membantu ibunya berdagang kue keliling kampung. Dari ajaran ruang lingkup keluarga juga yang membuat para aktor dapat mandiri. Dan juga karena telah pergi merantau dan jauh dari sanak keluarga yang membuat mereka jauh lebih mandiri dan tidak bergantung dengan orang lain. Karena bermodalkan relatif kecil ini para pedagang kaki lima sangat mengandalkan dirinya serta tenaganya sendiri. Tapi mereka cukup menikmati menjadi pedagang kaki lima yang mandiri karena tidak ada yang mengatur. Semua kendali perdagangan ada pada pedagang kaki lima itu 
sendiri. Kata salah satu pedagang kaki lima tidak perlu memikir di gaji atau memberi gaji. Kita giat bekerja maka hasilnya juga kita dapatkan sendiri.

\subsection{Variasi Trajektori Kehidupan Pedagang Kaki Lima}

Trajektori berbicara mengenai posisi para aktor dan lintasan kehidupan para aktor. Para aktor ini terlibat dalam ranah sosialyang berbentuk sebagai seorang pelaku bisnis. Pelaku bisnis yang bermodalkan relatif kecil, yang tidak memiliki skill yang memadai serta mengalami pergeseran dalam kehidupan. Dalam kehidupan pedagang kaki lima pergeseran tentunya sering mereka alami. Dari awal pedagang yang tidak mempunnyai langganan menjadi punya langganan, yang tadinya berjualan hanya satu macam barang sekarang jadi bermacam- macam. Ini hanya merupakan contoh kecil dari pedagang kaki lima yang mempunnyai rute atau lintasan yang sedikit baik. Ada pula pedagang kaki lima yang mengalami rute yang kurang memihak kepada mereka. Contohnya yang awalnya mempunyai tempat yang tetap sekarang telah di gusur dan berhenti berjualan, ada pula yang tidak kuat bersaing karena mengalami kebangkrutan karena modal yang terikat dengan rentenir juga dialami dari salah satu pedagang kaki lima ini.

\subsection{Strategi Dan Perjuangan Bisnis Pedagang Kaki Lima di Pasar Pagi}

Ranah perjuangan pedagang kaki lima dapat dikatakan jauh lebih berat karena dihadapkan dengan medan yang tidak bersahabat. Perbedaan cara berdagang, lokasi berdagang dan menjamurnaya pelaku bisnis di sektor informal membuat para pedagang kaki lima ini harus jauh lebih tepat mengatur strategi dalam mengumpulkan modal-modal mereka. Di lapangan pedagang kaki lima juga mengatur strategi bagaimanana mereka dapat mempertahankan usaha mereka. Dari penjelasan di atas penulis akan menjabarkan bagaimana strategi dan perjuangan pedagang kaki lima dalam mengumpulkan modal serta mengkonversikan modalmodal mereka dalam mempertahankan usahanya

\subsection{Strategi Pedagang Kaki Lima Dalam Mengumpulkan Modal Material}

Strategi mereka dalam mengumpulkan modal material juga sangat beragam. Ada dari salah satu aktor yang menggadaikan barang berharga mereka seperti emas, STNK motor di tempat penggadaian. Ada juga dari mereka yang meminjam dengan rentenir dan bunga yang diberikan lumayan besar dan juga meminjam dari sanak keluarga dan bahkan ada juga yang menggunakan tabungannya sendiri. Strategi dalam pengumpulan para pedagang kaki lima ini tentunya sangat bermacam-macam. Tetapi dengan cara mereka meminjam modal materi untuk modal awal tentunya para pedagang kaki lima ini lebih giat untuk mengembalikan modal material itu. Modal material yang keuntungannya awalnya harus dikembalikan kepada orang lain sekarang sisa dari keuntungan itu dapat dijadikan sebuah keuntungan bagi mereka sendiri.

\subsection{Strategi Pedagang Kaki Lima Dalam Mengumpulkan Modal Budaya}

Strategi pedagang kaki lima dalam mengumpulkan modal budaya adalah dengan cara berlaku baik kepada orang lain termasuk sesama pedagang kaki lima, konsumen dan lain- lain. Cara berbicara juga merupakan modal budaya yang mereka miliki dalam membangun hubungan-hubungan yang baik. Dengan memiliki pembawaan yang baik, sopan dalam berbicara tentunya para aktor ini memiliki kedudukankedudukan sosial tersendiri bagi para relasinya. Modal- modal budaya ini para aktor dapatkan dari ajaran mereka dari lingkungan keluarga, lingkungan sosial, serta pembawaan dari diri mereka.

\subsection{Strategi Pedagang Kaki Lima Dalam Mengumpulkan Modal Sosial}

Pedagang kaki lima membangun suatu jaringan bukan hanya dengan sesama pedagang kaki lima. Pedagang kaki lima juga membangun sebuah hubungan sosial dengan konsumen, pelaku bisnis bermodalkan besar, peminjam modal, aparatur pemerintahan sampai ke aliansi-aliansi mahasiswa. Manfaat dari membangun sebuah jaringan serta hubungan yang kuat ini adalah agar para pedagang kaki lima ini mendapatkan posisi yang kuat ketika berjualan. Untuk dapat membangun jaringan yang kuat tidak sedikit dari mereka yang membangun sebuah ikatan emosional kepada mereka yang memperkuat posisi mereka. Para pedagang kaki lima membangun sebauah jaringan kepada aliansi- aliansi mahasiswa agar jika terjadi relokasi atau penggusuran mereka akan dapat dibantu oleh mereka agar mendapatkan posisi yang kuat di arena mereka berdagang. Membangun jaringan yang kuat kepada mereka yang bermodalkan relatif besar adalah jika posisi berdagang para pedagang kaki lima ini di depan emper toko para pemodal besar ini. Mereka akan mempunyai posisi yang kuat karena telah mendapatkan izin dari si tuan pemilik toko. Dan membangun jaringan kepada pemilik modal (boss bandar) adalah dengan tujuan mendapatkan pinjaman modal apabila kekurangan modal material dan ingin merintis usaha dan memulai usaha baru. Hubungan yang baik berupa modal sosial dengan pemilik modal tentunya akan menguntungkan bagi para aktor dalam peminjaman modal. 


\subsection{Strategi Pedagang Kaki Lima Dalam Mengumpulka Modal Simbolik}

Modal simbolik tidak lepas dari kekuasaan simbolik. Akan tetapi bagi actor pedagang kaki lima ini modal simbolik merupakan kekhasan tertentu yang mereka miliki dalam berdagang. Dari kekhasan ini bertujuan agar konsumen dapat selalu mengingat dagangan mereka untuk dapat kembali berbelanja di lapak mereka

\subsection{Strategi dan Konversi Modal- Modal}

Dalam menjalani ranah bisnis sebagai pedagang bermodalkan relatif kecil tentunya para actor ini harus memiliki strategi dalam mengkonversikan modal-modal mereka. Bentuk konversi modal dari para aktor tentunya sangat berbeda-beda. Tujuan mereka dalam mengkonversikan modal adalah untuk dapat mempertahankan usahanya dan mencukupi kehidupan sehari-hari

\subsection{Konversi Modal Material Ke Modal Simbolik}

Awal dari keuntungan kebanyakan digunakan para aktor untuk mengembalikan peminjaman modal awal mereka. Kemudian dari sebagian aktor ada yang mengkonversikan modal mereka ke modal simbolik. Bentuk trannsformasi modal ini bertujuan sebagai penunjang mereka dalam berdagang dan kekhasan dagangan mereka agar selalu diingat oleh konsumen

\subsection{Konversi Modal Budaya Ke Modal Sosial}

Modal budaya ini dapat mereka konversikan ke modal sosial dengan membentuk sebuah organisasi gerakan contohnya. Dengan membuat organisasi gerakan tentunya akan memperkuat posisi mereka jika terjadi relokasi. Dengan modal budaya yang baik maka akan tercipta kekerabatan yang baik juga dengan sesama pedagang kaki lima. Modal budaya ini dapat mereka transformasikan dalam bentuk modal sosial sebagai bentuk hubungan serta jaringan kekerabatan sesama individual.

\section{KESIMPULAN}

Kelurahan Pasar pagi merupakan arena yang strategis bagi para pelaku bisnis yang bermodalak relatif besar sampai ke yang terkecil. Keseluruhan praktik yang dilakukan oleh pedagang kaki lima ini merupakan tuntutan serta peran hidup para aktor ini yang bergelut pada ranah bisnis yang bermodalkan relatif kecil. Strategi dan perjuangan para pedagang kaki lima dalam mempertahankan usahanya di arena ini dipenuhi dengan persaingan. Karena selain bersaing dengan sesama pedagang kaki lima para aktor ini juga harus mampu bersaing dengan mereka yang mempunyai modal relatif besar seperti maal dan toko-toko. Para pedagang kaki lima ini dengan segala usaha dengan mengandalkan modal sosial serta modal budaya para aktor ini juga mampu menarik minat konsumen serta membangun jarinagan serta hubungan-hubungan yang kuat. Habitus dari pedagang kaki lima ini mencakup sebuah kemandirian yang mereka bawa semenjak masih kecil. Penerepan yang diajarkan oleh keluarga mereka membuat para aktor ini tidak menjadai kaku untuk dapat bertahan dari segala problematik kehidupan. Para pedagang kaki lima ini sangatlah mempunnyai trajektori yang menarik di bandingkan para pemilik modal besar. Ada dari mereka yang mengalami rute kehidupan yang akan tergusur lalu berhenti berdagang, ada juga dari mereka yang mengalami trajektori dari menjadi pedagang kaki lima kemudian mendapatkan lokasi berdagang di dalam pasar dan ada pula yang sangat menikmati berjualan menjadi pedagang kaki lima karena menganggap lebih dekat dengan konsumen. Tentunya strategi-strategi serta kekuatan-kekuatan yang dimiliki oleh para pedagang kai lima ini sangatlah berbeda. itu yang membuat praktik di lapangan menjadi beraneka ragam.

\section{DAFTAR PUSTAKA}

Alisjahbana. 2005. Marginalisasi Sektor Informal Perkotaan. Yogyakarta. ITS Press.

Alisjahbana. 2005. Sisi Gelap Perkembangan Kota. Yogyakarta. LaksBang Pressindo

Bagus. 2005. (Habitus x modal) + Ranah $=$ Praktik. Bandung. Jalasutra. Manning, Chris dan Tadjuddin Noer Effendi. 1996. Urbanisasi, Pengangguran, dan Sektor Informal di Kota. Jakarta: Yayasan Obor Indonesia. BASIS, 2003, Edisi Khusus Pierre Bourdieu, November-Desember 2003 